Published in final edited form as:

Xin Li Xие Bao. 2008 January 1; 40(10): 1073-1087.

\title{
The End of Behavioral Genetics?
}

\author{
Matt McGue ${ }^{1,2}$ \\ ${ }^{1}$ Department of Psychology, University of Minnesota \\ ${ }^{2}$ Institute of Public Health, University of Southern Denmark
}

\begin{abstract}
Although genetic models were in the ascendance within psychology during the early $20^{\text {th }}$ century, the association of early behavioral genetic research with the eugenics movement served to discredit the field in the eyes of many. Twin and adoption studies throughout the latter half of the $20^{\text {th }}$ century helped to reestablish the importance of behavioral genetic models and set the stage for the current focus of the field on developing and testing models of gene-environment interplay. Research findings on developmental behavioral genetic research, gene-environment interaction, and the use of behavioral genetic models to test causal hypotheses are used to highlight the contributions of contemporary behavioral genetic research to psychological research. It is argued that future efforts to investigate models of gene-environment interplay will depend heavily of the field's ability to identify the specific genetic variants that contribute to individual differences in behavior. The anticipated yield from genome-wide association studies gives much reason to be optimistic about the future vitality of behavior genetics.
\end{abstract}

The end of behavioral genetics? Recently the developmental psychologist, Richard Lerner, published a commentary entitled, "Another nine-inch nail for behavioral geneticists!" (Lerner, 2006). Lerner began his commentary with the lament, "Why do we have to keep reinterring behavior genetics" (p. 337), but concluded confident in the belief that a critical analysis of IQ adoption studies (Richardson \& Norgate, 2006) had finally help put the field irretrievably where he felt it belonged, presumably six feet under. Singing the death knell of behavior genetics has been a popular pastime for critics of the field over the past 100 years, but critiques like that by Richardson and Norgate (2006) have done little to dampen interest in behavioral genetics. It is not that behavioral genetics is above criticism; quite the contrary there is much to criticize about the field. Rather, the reason Lerner and his fellow critics are engaged in the Sisyphean task of "reinterring" behavioral genetics is that they have failed to recognize the enormous impact the field has had on the way psychologists think about individual differences in behavior; they have failed to understand the essential nature of the behavioral genetic research paradigm.

The purpose of this special issue of Acta Psychologica Sinica is, of course, to recognize the vitality of contemporary behavioral genetic research, not to mourn its demise. Nonetheless, even as we highlight research progress in the field, it can be helpful to consider how others have reacted to behavioral genetic findings, even the field's most enthusiastic critics. Behavioral genetics has often been caught up in controversy, sometimes unfairly, and an assessment of its current impact on psychology can benefit from both a discussion of the field's historical roots, with which I will begin, and speculation over its possible future, where I will end.

Correspondence: Matt McGue, Department of Psychology, University of Minnesota, 75 East River Rd., Minneapolis, MN 55455, (612)-625-8305 (Voice); (612)-626-2079 (FAX), mcgue001@umn.edu. 
The specific charge for this special issue is to highlight contemporary behavioral genetic research. In a single article it is no longer possible to comprehensively survey the full range of behavioral genetic research. As an alternative, I have elected to highlight new developments in behavioral genetics by describing how selected findings from the University of Minnesota, and especially from the Minnesota Center for Twin and Family Research (MCTFR), fit in with larger developments in the field. The MCTFR was begun in 1988 by David Lykken, Auke Tellegen, William Iacono and myself when we initiated the Minnesota Twin Family Study (MTFS), a longitudinal study of approximately 1400 families, each consisting of a pair of adolescent like-sex twins and their parents (Iacono, McGue, \& Krueger, 2007). We have continued to follow these families every 3-4 years as the twins have passed through mid- and late-adolescence through their early to late 20s (McGue \& Iacono, 2008). In 1998, we initiated the Sibling Interaction and Behavior Study (SIBS), a parallel longitudinal study of 409 adoptive and 208 non-adoptive families, each consisting of a pair of adolescents and their rearing parents (McGue et al., 2007). As in the MTFS, the adolescent participants in SIBS have been followed through adolescence into early adulthood. Together, MTFS and SIBS provide a powerful foundation for engaging in developmental behavioral genetic research and addressing the important research questions that define the field today.

\section{BEHAVIORAL GENETICS: THE HISTORICAL CONTEXT}

\section{The Early Rise and Early Demise of Behavioral Genetics}

When the nascent field of psychology was taking form at the end of the $19^{\text {th }}$ century, it had a decidedly Darwinian orientation. In large measure this owed to the efforts of Francis Galton, Charles Darwin's cousin. Galton was a polymath who made an extraordinary number of important contributions to science. He developed the fingerprint method still used today in forensics, started the field of biometry with his student Karl Pearson, and was one of the founders of the journal Nature (Gillham, 2001). His cousin's publication of the Origin of Species led Galton to dedicate his scientific career to the application of Darwinian principles to human behavior. His 1869 publication, Hereditary Genius (Galton, 1869), is the first rigorous scientific investigation of the familial transmission of a human behavioral trait, in this case social achievement, and inaugurated the field of human behavioral genetics. Hereditary Genius and other empirical investigations led Galton to the conclusion that, "nature prevails enormously over nurture when the differences of nurture do not exceed what is commonly to be found among persons of the same rank in society and in the same country" (Galton, 1876) (p. 404)

Galton believed inherited factors had a substantial influence on individual differences in behavior. As the quote indicates, however, he did not believe that nurture was unimportant, especially at the extremes of economic deprivation and privilege. Nonetheless, the ascendance of biological thinking in the early days of psychology led some to advocate a doctrine of genetic determinism. Henry Goddard, one of the leading figures in developmental psychology in the early $20^{\text {th }}$ century, argued that, “. $\ldots$ grade of intelligence or mental level for each individual is determined by the kind of chromosomes that come together with the union of the germ cells ... [and] is but little affected by any later influence ..." (p.1) (Goddard, 1920). For Goddard, and others like him, our fates were largely sealed at the moment of conception and little affected by families, schools and social institutions. Ironically, the belief in genetic determinism when combined with another of Galton's intellectual contributions undermined his early efforts to place psychology on a behavioral genetic foundation. In 1883, Galton (1883) introduced the term eugenics (Greek for well [eu] born [genic]) to denote how knowledge of the principles of the inheritance of human behavior might be applied to pressing social problems: “ . . if talented men were mated with talented women, of the same mental and physical characters as themselves, generation after generation, we might produce a highly-bred human race, with no more tendency to revert to meaner ancestral types than is shown by our long-established breeds 
of race-horses and fox-hounds." (Galton, 1865) (p. 318). Even if Galton's original conceptualization of eugenics was relatively benign (i.e., emphasizing educational efforts or, at the most extreme, "positive" eugenic practices such as paying the 'most talented' to reproduce), it eventually devolved into repressive proscriptive efforts (i.e., forced sterilization and restrictive immigration laws). As most know, eugenics was ultimately seized upon by the Nazis in an attempt to provide a scientific rationale for their racial hygiene laws and the Holocaust.

Behavioral genetics was nearly completely discredited by its early association with the eugenics movement. Few intellectuals wanted to be associated with a scientific endeavour perceived to have contributed to the Nazi's repressive policies, no matter how indirectly. The demise of biological accounts within psychology created a vacuum that was filled by a view of human nature, tabula rasa, that was arguably every bit as radical as that offered by the genetic determinists (Pinker, 2002). Many will be familiar with the following boast from John B. Watson, the founder of radical behaviorism: "Give me a dozen healthy infants well-formed, and my own specified world to bring them up in and I'll guarantee to take any one at random and train him to become any type of specialist I might select -- a doctor, lawyer, artist, merchantchief, and, yes, even beggar-man and thief, regardless of his talents, penchants, tendencies, abilities, vocations, and race of his ancestor." (Watson, 1930) (p.82). Less familiar may be the next sentence in Watson's quote, "I am going beyond my facts and I admit it, but so have the advocates of the contrary and they have been doing it for many thousands of years.", which indicates that Watson knew he was being hyperbolic. Whether Watson could make good on his boast was largely irrelevant, however, as purely environmental accounts would dominate within psychology and psychiatry for much of the next 50 years. For example, schizophrenia was attributed to the machinations of mothers (i.e., the "schizophrenic mother") (FrommReichmann, 1948), while personality was considered to be a reflection of the home you grew up in (Mischel, 1981). By the mid-20 $0^{\text {th }}$ century, the "Blank Slate" model of human nature had taken a strong hold on the field (Harris, 1998).

\section{Twin and Adoption Studies and the Reemergence of Behavioral Genetic Research}

Even though it had lost most of its popularity by the middle of the $20^{\text {th }}$ century, behavioral genetics was not without its adherents. Initially in Western Europe and increasingly in the U.S., a small group of researchers undertook a set of investigations that would challenge and eventually undermine the Blank Slate model. Using traditional research methodologies such as adoption and twin studies, these researchers accumulated a set of research findings that in aggregate provided compelling evidence for the existence of genetic influences on individual differences in a wide range of behavioral outcomes.

Adoption Studies-The logic of the adoption study is relatively straightforward: If genetic factors are important, then individuals should to some degree resemble their biological parents regardless of whether they had been reared by those parents. This is precisely what behavioral geneticists have repeatedly found. For traits as diverse as intellectual ability (Teasdale \& Owen, 1984), schizophrenia (Heston, 1966), mood disorders (Mendlewicz \& Rainer, 1977), alcoholism (Cloninger, Bohman, \& Sigvardsson, 1981), and criminal behavior (Mednick, Gabrielli, \& Hutchings, 1984) researchers have reported significant resemblance between biological parents and their reared-away offspring. At the same time, and somewhat unexpectedly, many but not all of these researchers also failed to find significant behavioral resemblance among adoptive relatives. For example, being reared by a parent with schizophrenia (Wender, Rosenthal, Ketty, Schulsinger, \& Welner, 1974); an affective disorder (Mendlewicz \& Rainer, 1977), or criminality (Mednick et al., 1984) was not associated with increased offspring risk so long as they were not genetically related to the rearing parents. These early findings hinted at what now is a fairly well established behavioral genetic finding: 
While environmental effects on human behavior are pervasive and strong, they appear predominantly to contribute to differences rather than similarities among reared-together relatives (Plomin \& Daniels, 1987).

Reared-together Twin Studies-By far the most common behavioral genetic design is the study of reared-together twins. Twins are relatively common, in some countries accounting for as much as $2-4 \%$ of the population, and the existence of national registries in many countries (Busjahn \& Hur, 2006; Kaprio, 2006; Lichtenstein et al., 2006; Skytthe et al., 2006) and some U.S. states (Lykken, Bouchard, McGue, \& Tellegen, 1990; Rhea, Gross, Haberstick, \& Corley, 2006) has made it relatively easy to undertake large-scale studies of twins. Although more recent twin registries are being established in many Asian countries as well (Ando et al., 2006; He, Ge, Zheng, Huang, \& Zeng, 2006; Hur, Shin, Jeong, \& Han, 2006; Li et al., 2006; Pang et al., 2006). In a twin study, the inference of the existence of a genetic influence is based on the similarity of the two types of twins. That is, if genetic factors are important, then monozygotic (MZ) twins, who are genetically identical, should be more similar than (samesex) dizygotic (DZ) twins, who like ordinary siblings share 50\% of their segregating genes.

In multiple studies of behavioral traits as diverse as intellectual ability (McGue, Bouchard, Iacono, \& Lykken, 1993), personality (Finkel \& McGue, 1997), psychopathology (I.I. Gottesman \& Shields, 1972) and even social attitudes (Martin et al., 1986) and divorce (McGue \& Lykken, 1992) behavioral geneticists have reported greater similarity among MZ than DZ twins. Figure 1 provides an example of the nature of these findings in terms of twin concordances (i.e., risk to the cotwins of affected individuals) for various types of behavioral disorders drawn from a review of behavioral genetic research (McGue \& Bouchard, 1997). As can be seen, even though concordances vary from one disorder to the next, they are always higher among $\mathrm{MZ}$ as compared to DZ twins, suggesting that genetic factors influence psychopathology risk. Alternatively, concordances among MZ twins are never perfect and indeed generally fall in the moderate range, 4 to .6. Since MZ twins are genetically identical, this lack of perfect concordance must be due to environmental factors, albeit those that contribute to differences rather than similarities among family members since in the case of Figure 1 all twins have been reared-together.

Reared-Apart Twin Studies-Far less common than either of the two traditional methodologies used by behavioral geneticists is their intersection, the study of adopted twins. There have been approximately a half dozen systematic investigations of reared-apart twins published in the literature and findings from these studies provide constructive replication of findings from adoption and reared-apart twin studies. That is, there is significant psychological similarity between the two members of an MZ twin pair even when they have been reared in separate homes from infancy. This is perhaps made most evident by findings from the Minnesota Twin Study of Twins Reared Apart (MISTRA), which reported similarity for a range of psychological characteristics in a sample of more than 100 pairs of reared-apart twins (T. J. J. Bouchard, Lykken, McGue, Segal, \& Tellegen, 1990). Figure 2 summarizes findings from this study in terms of the correlation among reared-together and reared-apart twins averaged across multiple indicators clustered in four major domains of psychological functioning. Three general trends are evident. First, reared-apart MZ twin similarity ranges from moderate (for social attitudes) to strong (for IQ), implicating genetic influences, albeit of varying magnitude, across a range of psychological outcomes. Second, MZ twin similarity in each domain is never perfect, implicating the existence of environmental influences, which for social attitudes and interests account for the majority of phenotypic variance. Finally except for IQ, reared-together MZ twins are not much more similar than reared-apart MZ twins, suggesting that common rearing may not have a substantial effect on individual differences in the domains represented. 
Biometrical Methods of Analysis-Qualitative analyses of twin and adoption studies support the existence of both genetic and environmental influences on a broad range of behavioral outcomes. Quantitative analysis of twin and family data help to strengthen and refine these conclusions by estimating effect size, assessing statistical model fit, and identifying trends in the data that might not otherwise be apparent. Biometrical analysis involves fitting explicit models of genetic and environmental influence to twin and family data (Neale \& Cardon, 1992). The biometrical approach is based on the assumption that variance in a quantitative phenotype (e.g., IQ, a personality scale score, or a measure of speed of response) can be decomposed into its underlying determinants, with most research focusing on the following three major variance components: additive genetic factors, shared environmental factors (i.e., those environmental factors that are shared by reared together relatives and thus potentially contribute to their behavioral similarity), and non-shared environmental factors (i.e., those environmental factors that are not shared by reared-together relatives and thus potentially contribute to their behavioral differences). Because the biometrical approach is based on a set of simplifying assumptions (e.g., most biometrical analyses do not make explicit allowance for gene-environment interaction effects), results using this approach are at best approximations. Nonetheless, these approximations have proven to provide a useful initial description of the major contributors to individual differences in behavior.

Biometrical models can be fit to individual studies; they can also be fit to data aggregated across multiple studies. The study by Chipuer et al. (Chipuer, Rovine, \& Plomin, 1990) illustrates both the biometrical approach and the use of aggregated data. These researchers fit various biometrical models to the aggregate familial IQ correlations data published by Bouchard and McGue (T. J. Bouchard \& McGue, 1981). Qualitative analysis of the twin and family correlations implicated the existence of genetic influences on IQ (e.g., the pooled MZ correlations for IQ was .86 on 4672 pairs, while the comparable value for DZ twins was .60 on 5533 pairs). Biometrical analysis allowed these investigators to formalize and quantify impressions gained through informal qualitative analyses. Based on the fitted parameter estimates, these researchers concluded that approximately 51\% of IQ variance was associated with genetic factors, $35 \%$ with shared environmental factors, and $14 \%$ with non-shared environmental factors. Subsequent studies have reported similar summary estimates for IQ (Devlin, Daniels, \& Roeder, 1997).

\section{CONTEMPORARY BEHAVIORAL GENETIC RESEARCH}

The focus on establishing the existence of heritable influences on behavior that dominated within the field throughout much of the twentieth century led to concerns that behavioral geneticists were seeking to resurrect the doctrine of genetic determination (Feldman \& Lewontin, 1975). Even if historically grounded, these critiques failed to recognize the need to reestablish the significance of genetic factors as a counterforce to Blank Slate approaches. Indeed, if anything, behavioral genetic research has done more to undermine than support deterministic arguments (Bioethics, 2002). Establishing unequivocally the importance of genetic contributions to behavior in the $20^{\text {th }}$ century has allowed behavioral geneticists to move on to explore more important questions about the mechanisms by which genetic and environmental factors combine to jointly influence behavior in the $21^{\text {st }}$ (Rutter \& Silberg, 2002). A systematic review of contemporary behavioral genetic research is well beyond the scope of the present article. As an alternative, we illustrate the focus of contemporary behavioral genetic research on joint models of genetic and environmental effects by describing selected findings from the MCTFR as well as related findings from the larger field.

Behavioral Genetics and Development-One of the more provocative findings to emerge from the behavioral genetic literature is the observation that genetic influences on behavior appear to increase with age while shared environmental influences wane. Although 
this pattern was first observed with IQ (McCartney, Harris, \& Bernieri, 1990; McGue et al., 1993), the same pattern has been reported for a wide range of behavioral traits including political attitudes (Eaves et al., 1997), antisocial behavior (Lyons et al., 1995), parent-child relations (McGue, Elkins, Walden, \& Iacono, 2005), religiousness (L. B. Koenig, McGue, \& Iacono, 2008; L.B. Koenig, McGue, Krueger, \& Bouchard, 2005), and peer group affiliation (Kendler et al., 2007). In a recent meta-analysis, Bergen et al. (Bergen, Gardner, \& Kendler, 2007) showed that this pattern was most evident during the transition from adolescence to early adulthood, a developmental period also characterized by increasing individual control over the nature and range of experience.

Rather than interpreting increasing genetic influence as evidence of the increasing genetic determination of behavior, most behavioral geneticists interpret this pattern as implicating processes of gene-environment interplay. Anticipating developmental behavioral genetic findings from the last 15 years, Scarr and McCartney (Scarr \& McCartney, 1983) proposed a model of gene-environment correlation that predicts developmental changes in heritable effects. Behavioral geneticists distinguish three major processes by which genetic and environmental effects can come to be correlated. Passive gene-environment correlation arises because parents who transmit genes to their children also help to create the environments their children are reared in. For example, high-ability parents not only transmit to their children genes that support intellectual achievement, they are also likely to provide a rearing environment that is intellectual enriched. Evocative gene-environment correlation arises because the environments individuals experience are in part a function of the way parents, teachers, friends, and others react to their (genetically-influenced) behavior. For example, the social environments experienced by two children, the first overactive and oppositional, the second restrained and compliant, are likely to be markedly different in part because of differences in the ways the two children act. Finally, active gene-environment correlation refers to the process by which individuals actively construct their environments by selecting experiences that reinforce or complement their inherited abilities, dispositions and interests.

Scarr and McCartney (1983) hypothesized that as individuals grow older they gain increasing control over experiential choices, which consequently increasingly reflect their geneticallyinfluenced propensities. These increases in active gene-environment correlational processes are accompanied by decreases in passive gene-environmental effects reflecting diminishing parental influences. The result is the classic pattern of developmental increases in heritability and decreases in shared environmental influences. Research at the MCTFR supports the importance of gene-environment correlational processes during adolescence and early adulthood. For example, we have found that individuals who engage in problem behavior early in adolescence are at a substantial increased risk of substance abuse and mental health problems in early adulthood (McGue \& Iacono, 2005) and that this association is due primarily to genetic effects common to early problem behavior and adult mental health problems (McGue, Iacono, $\&$ Krueger, 2006). At the same time, our findings do not support genetic determination of mental health outcomes, as early problem behavior appears to affect adult risk in part because its expression increases the likelihood that the developing adolescent is exposed to deviant peers, has a conflicted relationship with his or her parents, and is disengaged from school (M. A. Keyes, Iacono, \& McGue, 2007).

Gene-Environment Interaction: A New Behavioral Genetic Paradigm-Geneenvironment interaction $(\mathrm{G} \times \mathrm{E})$ refers to non-additive combination of genetic and environmental effects on phenotype. Although long a focus of theoretical interest, the systematic investigation of $\mathrm{G} \times \mathrm{E}$ in human behavioral genetics has only recently been made feasible by the development of both biometric approaches, which provide overall tests for the existence of GXE (Purcell, 2002), and measured genotype approaches, which test hypotheses about the interaction of specific functional genetic polymorphisms with specific environmental 
agents (Moffitt, Caspi, \& Rutter, 2005). The growing interest in G×E can be seen in Figure 3, which charts entries to "gene environment interaction" in the Thomson Institute for Scientific Information (ISI) database over the past 20 years. In 1988 there was not a single entry to G×E in the ISI database; last year there were more than 400 . G $\times$ E clearly represents a major paradigm shift among those investigating genetic contributions to human health and well being.

Formally, $\mathrm{G} \times \mathrm{E}$ occurs when genetic effects are conditional on environmental exposure. Shanahan and Hofer (Shanahan \& Hofer, 2005) have described the various forms of G×E; two of which are of particular interest to behavioral geneticists. First, $\mathrm{G} \times \mathrm{E}$ can arise when genetic effects are either triggered or amplified by exposure to a high-risk environment. Shanahan and Hofer termed this form of G×E Contextual Triggering, although most will recognize this as an instance of the Diathesis-Stress model. The Diathesis-Stress model was originally proposed to account for the development of schizophrenia (Zubin \& Spring, 1977), but is now applied to a wide range of psychopathological conditions. The most impressive support for this form of $\mathrm{G} \times \mathrm{E}$ in the behavioral genetic literature comes from a series of influential publications using the measured genotype approach by Caspi and colleagues. For example, Caspi et al. (Caspi et al., 2002) reported that a functional polymorphism in the MAO-A gene was associated with increased violence only among those who had been maltreated in youth, while Caspi et al. (Caspi et al., 2003) found that a functional polymorphism in the promoter of the serotonin transporter gene was associated with increased risk for depression only among those who had experienced high levels of psychological stress.

Shanahan and Hofer termed the second form of GxE Social Context as Social Control. This form of $\mathrm{G} \times \mathrm{E}$ refers to the existence of environments that suppress the expression of genetic effects. Typically, this suppression occurs because the environment limits individual choice. For example, Turkheimer and colleagues (Turkheimer, Haley, Waldron, D'Onofrio, \& Gottesman, 2003) showed, using the biometric approach to $\mathrm{G} \times \mathrm{E}$, that genetic influences on intellectual achievement are suppressed in high poverty environments, presumably because impoverished environments provide limited opportunities to pursue and engage in intellectual pursuits. Similarly, Legrand and colleagues (Legrand, Keyes, McGue, Iacono, \& Krueger, 2008) using MCTFR data found that genetic effects on multiple indicators of adolescent disinhibited behavior were suppressed in rural as compared to urban environments, presumably because social monitoring of adolescent behavior, which is more likely to occur in rural as compared to urban environments, limits individual choice.

Although clearly on the ascendance, GXE approaches to human behavior are still at the initial stages of inquiry. Two general issues have been raised concerning the application of $\mathrm{G} \times \mathrm{E}$ approaches within behavioral genetics. First, are $\mathrm{G} \times \mathrm{E}$ effects replicable? It is well known that interactions are less statistically reliable than main effects (Wahlsten, 1990), so that we might expect a priori that there will be difficulties in replicating $\mathrm{G} \times \mathrm{E}$ findings. Nonetheless, some $\mathrm{G} \times \mathrm{E}$ findings have accumulated an impressive record of replication. For example, the interaction between stress and the polymorphism in the promoter region of the serotonin transporter in the etiology of depression originally reported by Caspi et al. (Caspi et al., 2003) has been replicated in the vast majority of published attempts to replicate (Uher \& McGuffin, 2008), while at least two independent studies have replicated Turkheimer et al.'s (2003) finding that the heritability of IQ is low in impoverished environments (Harden, Turkheimer, \& Loehlin, 2007; Rowe, Jacobson, \& Van den Oord, 1999).

A second issue concerns the need for a theoretical framework to guide $\mathrm{G} \times \mathrm{E}$ research in human behavioral genetics. Shanahan and Hofer's (2005) review suggests that there may generalizable $\mathrm{G} \times \mathrm{E}$ effects on behavior. Nonetheless, much of the current research on $\mathrm{G} \times \mathrm{E}$ is theoretically ad hoc, with minimal concern over whether $\mathrm{G} \times \mathrm{E}$ effects generalize across conceptually linked phenotypes and types of environmental exposure. Recently, we have begun to explore the 
general nature of $\mathrm{G} \times \mathrm{E}$ effects through analysis of MCTFR data. For example in the previously cited study by Legrand et al. (2008), the moderating effect of urban/rural rearing on genetic influences was not specific to adolescent alcohol use, as had been indicated by previous research (Rose, Dick, Viken, \& Kaprio, 2001), but rather was characteristic of multiple indicators of adolescent disinhibitory psychopathology. Extending this line of inquiry with MCTFR data, Hicks et al. (2008) sought to determine whether the same form of G×E held across alternative forms of externalizing psychopathology and multiple measures of environmental adversity. For these conceptually related phenotypes and exposures there was strong evidence for a general form of $\mathrm{G} \times \mathrm{E}$ - in every case environmental adversity was found to amplify the magnitude of genetic influences on externalizing psychopathology.

Behavioral Genetics and Causal Inference-One of the greatest challenges in nonexperimental disciplines is the drawing of causal inferences from observational data. Although psychologists have attempted to overcome the limitations of observational data through use of structural equation modeling (SEM), the typical application of SEM is burdened by untested assumptions and the extent to which this approach has fostered valid causal inference remains unclear (Freedman, 2006). Alternatively, psychologists have attempted to take advantage of so-called "experiments of nature", chance exposures that mimic experimental randomization even if they do not constitute true experiments. The difficulty with this latter strategy of course is that experiments of nature depend on serendipitous events that are outside the investigator's control. Rutter (Rutter, 2007; Rutter, Pickles, Murray, \& Eaves, 2001) has recently shown, however, that several behavioral genetic research designs constitute experiments of nature and consequently provide unique opportunities for rigorous evaluation of causal hypotheses with observational data. We illustrate this aspect of contemporary behavioral genetic research with two examples of recent MCTFR research.

Adoption Studies and Causal Hypotheses About the Familial Transmission of Risk: One of the most salient features of common mental disorders is that they aggregate in families. Whether it is a mood disorder (Currier, Mann, Oquendo, Galfalvy, \& Mann, 2006; Weissman et al., 2006), an impulse-control disorder (Faraone \& Biederman, 1997), a substance use disorder (Hicks, Krueger, Iacono, McGue, \& Patrick, 2004; K.R. Merikangas et al., 1998), or an anxiety disorder (K. R. Merikangas et al., 1998) the offspring of parents with a common mental disorder are at a substantially elevated risk of suffering the same disorder than are the offspring of unaffected parents. The familial transmission of psychopathology risk has implications for prevention, although to be effective the precise form prevention efforts take will likely depend on the mechanisms of familial transmission (Collins, Murphy, \& Bierman, 2004; Dierker, Avenevoli, Goldberg, \& Glantz, 2004). Adoption studies can help to explicate the nature of these familial associations.

This approach can be illustrated by describing our recent study on the familial transmission of smoking (M. Keyes, Legrand, Iacono, \& McGue, 2008). There is a substantial body of research showing that the adolescent offspring of smoking parents are more much more likely to smoke than the adolescent offspring of non-smoking parents (Jackson \& Henriksen, 1997; Otten, Engels, van de Ven, \& Bricker, 2007). Using the SIBS sample of adoptive and non-adoptive families, Keyes et al. (2008) sought to determine the extent to which parent smoking effects were genetically or environmentally mediated. As expected in non-adoptive families, parent smoking was significantly associated with excess risk of adolescent tobacco use; somewhat unexpectedly it was also associated with excess risk of alcohol use, marijuana use, and any disruptive disorder (the latter including oppositional defiant disorder, attention-deficit/ hyperactivity disorder, and conduct disorder) in these families. A parallel analysis in adoptive families can help to implicate genetic and psychosocial mechanisms of these parent effects. Consistent with environmental contributions to transmission, adoptive parent smoking was significantly associated with increased adolescent risk of both tobacco and marijuana use, 
although the strength of these associations was smaller than in the non-adoptive families implicating genetic contributions to transmission as well. Alternatively, adoptive parent smoking was not significantly associated with excess risk of alcohol use or disruptive disorders, suggesting that genetic factors may underlie these parent smoking effects. This pattern of results thus implicates the existence of two mechanisms whereby parent smoking affects offspring risk (Figure 4): 1) a primarily genetically-mediated pathway that conveys generalized vulnerability to disinhibitory psychopathology and substance abuse, and 2) a primarily environmentally-mediated pathway that conveys specific risk for smoking-related behavior. It would have been very difficult to uncover the dual nature of parent smoking risk without recourse to a natural experiment, like an adoption study.

Mendelian Randomization and a Novel Test of the Gateway Model: One of the most prominent models for the development of adolescent substance use is the Gateway Model, which was developed to account for the observation that adolescent substance use typically progresses from "softer" drugs like tobacco, alcohol and marijuana to "harder" drugs like cocaine and heroin (Kandel, 2002; Kandel, Yamaguchi, \& Chen, 1992). Specifically, the Gateway Model hypothesizes that the use of soft drugs directly increases the likelihood of the subsequent use of hard drugs by introducing adolescents to a drug using culture; that is, by serving as gateways. While there is little question that adolescent substance use typically progresses from softer to harder drugs, less certain is the causal basis for these associations does soft drug use really causally contribute to hard drug use (Golub \& Johnson, 1998). This is a difficult question to address, since it would be unethical to undertake a randomized experiment in which adolescents are exposed to gateway substances. Nonetheless, the Gateway Model, if accurate, has profound implications for prevention efforts. We recently proposed that the method of Mendelian Randomization (MR) provided a natural experiment to test the gateway hypothesis (Irons, McGue, Iacono, \& Oetting, 2007).

MR takes advantage of the random assortment of alleles that occurs during meiosis that can, under certain circumstances, be used as an analog of a true experiment. Specifically, if a functional polymorphism exists in a gene that affects exposure (i.e., alcohol use for the purposes here), then the effects of exposure can be determined by investigating how inherited variation in this polymorphism is related to the behavioral or disease outcomes thought to be causally linked to exposure. The major limitation with the MR approach lies, of course, in identifying a polymorphism that affects exposure but is not otherwise likely to affect outcome. In the case of alcohol use such a polymorphism exists.

Figure 5 depicts the metabolic pathway involved in the elimination of alcohol. Alcohol is first converted to acetaldehyde by the enzyme alcohol dehydrogenase (ADH), and acetaldehyde is converted to acetate by the enzyme aldehyde dehydrogenase (ALDH). The second step is the rate limiting step in the metabolic breakdown of alcohol, and levels of acetaldehyde are associated with most of the dysphoric effects of drinking (e.g., dizziness, nausea).

Consequently, genetic variation in the genes coding for the underlying enzymes, ALDH, and $\mathrm{ADH}$, might be expected to affect not only the rate of alcohol elimination but also the likelihood an individual experiences dysphoria when drinking. Indeed, this is what has been found, with variation in the rate-limiting enzyme, ALDH, having the most powerful effect on drinking behavior. Specifically, a genetic variant in the gene that codes for ALDH2, the mitochondrial form of ALDH, codes for a deficient form of the enzyme. Consequently, individuals who inherit one or more copies of this allele are more much more likely to experience alcohol-induced dysphoria and flushing, and are much less likely to drink heavily or become alcoholic than individuals who did not inherit the deficient variant (Harada, Agarwal, Goedde, Tagaki, \& Ishikawa, 1982). Significantly, this polymorphism exists only among East Asians, where nearly $50 \%$ of the population carries at least one copy of the deficient allele (Higuchi, Matsushita, Murayama, Tagaki, \& Hayashida, 1995). 
The ALDH2 polymorphism provides an ideal opportunity to use MR to test a key tenet of the gateway model. Genetic variation in ALDH2 is distributed randomly at meiosis and will affect exposure to alcohol. Moreover, ALDH2 is expressed only in liver, so it is highly unlikely that it would have any effect on behavioral outcomes other than its effect on drinking behavior. SIBS includes a large sample of adopted Asian-American adolescents, which Irons et al (2007) used to investigate the consequences of inheriting ALDH2 deficiency. As expected, inherited ALDH2 deficiency was significantly associated with reduced frequency of heavy drinking. That is, by chance some adolescents inherited a powerful protection against heavy drinking, but did inheriting this protection against drinking also result in their reduced use of other substances and delinquent behavior as the Gateway Model predicts? Contrary to this expectation, Irons et al. (2007) found no evidence for gateway effects. Those who inherited the deficient form of the ALDH2 allele were no less likely than those who did not to use tobacco, marijuana, or illicit drugs or to be delinquent and engage in antisocial acts. By indicating that the effects of ALDH2 deficiency did not extend beyond its primary effect on drinking behavior, this novel use of MR suggests that interventions that target adolescent alcohol use may have limited impact on other adolescent problem behaviors.

\section{THE FUTURE OF BEHAVIORAL GENETIC RESEARCH}

The possibility of technological breakthrough makes it risky, perhaps arrogant, to speculate about the future of any scientific discipline. Indeed, the focus of much behavioral genetic research today could not have been anticipated 20 or even 10 years ago. Nonetheless, while the precise nature of behavioral genetic research in the coming decades may be difficult to forecast, almost certain is that future progress will depend heavily on the discovery of the specific genes affecting behavior. Indeed, each of the three areas of contemporary behavioral genetic research highlighted above required knowledge of the specific genetic polymorphisms that underlie individual differences in behavior. Unfortunately, progress to date in identifying the specific genetic effects implied to exist in biometric analyses of behavioral data has been at best meager.

Several factors have contributed to the slow progress in identifying behaviorally-relevant genetic polymorphisms. It is important to recognize, however, that these problems are no different from those that have plagued gene identification efforts for a wide range of complex inherited diseases. Attempts to replicate initial positive findings in genetic association studies of behavioral as well as non-behavioral phenotypes have been much more likely to result in failure than success (Hirschhorn, Lohmueller, Byrne, \& Hirschhorn, 2002; Ioannidis, Ntzani, Trikalinos, \& Contopoulos-Ioannidis, 2001).

The association of the dopamine $\mathrm{D} 2$ receptor (DRD2) gene with alcoholism risk provides a useful example of the challenges of gene identification with complex behavioral phenotypes. In 1990, Blum and colleagues (1990) reported that 24 (69\%) of 35 alcoholics but only 7 (20\%) of 35 controls carried the $\mathrm{A}_{1}$ allele at a restriction fragment site downstream of the DRD2 locus. This corresponds to an impressive odds ratio (OR) of 8.73 (95\% confidence interval of 8.17 to 9.29), suggesting that genetic variation in DRD2 is a major contributor to alcoholism risk. Subsequent attempts to replicate Blum's findings produced some positive replications (Neiswanger, Hill, \& Kaplan, 1995; Noble, 1998) but many more failures to replicate (Gelernter et al., 1991; Kidd, 1993). While the inconsistent pattern of replication led some to dismiss the association as artifact (Pato, Macciardi, Pato, Verga, \& Kennedy, 1993), a recent meta-analysis of all published association studies suggests an alternative explanation (Smith, Watson, Gates, Ball, \& Foxcroft, 2008). Two findings from the meta-analysis are especially relevant to the discussion here. First, Smith et al. reported a pooled OR of 1.3, clearly much smaller than the original observation but nonetheless still statistically significant. Second, when the cumulative pooled OR was plotted against date of publication, it was found to decrease 
over time. That is, as more studies on the association of DRD2 with alcoholism were published, the pooled estimate of the size of the association decreased. This latter pattern is characteristic of what geneticists call the "Winner's Curse" (Goring, Terwilliger, \& Blangero, 2001). An initial finding of significant genetic association is often based on a small sample in which multiple phenotypes and multiple genetic markers may have been investigated. To be significant in a small sample, and thus justify publication, the effect size will need to be large, and likely be overestimated because of multiple testing. Consequently, attempts to replicate, which are typically based on larger samples where there is less opportunity to capitalize on chance findings due to multiple testing, will report smaller and sometimes nonsignificant effects sizes. The importance of the DRD2/alcoholism saga is that it has shown us that: 1) genetic association studies will require large samples (in the thousands rather than the hundreds) to produce statistically reliable results; and 2) the effect of any single genetic locus is likely to be very small - ORs of 1.1 to 1.3 for categorical outcomes and $<.5 \%$ of variance accounted for quantitative outcomes (Plomin, Kennedy, \& Craig, 2006).

Behavioral geneticists have adopted two strategies in an attempt to meet the challenges inherent to gene identification with behavioral conditions. Both strategies are being used at the MCTFR. The first is the endophenotype approach advocated by Gottesman and Gould (Gottesman, II $\&$ Gould, 2003). The essence of this strategy is to identify phenotypes that are intermediate between primary gene product and the behavioral outcome of interest. The expectation is that because these intermediate or endophenotypes are more proximal to the biological substrate than clinical phenotypes, it will be easier to identify the genes that affect their expression. The endophenotype approach holds great promise and indeed appears to have been successfully applied in the addictions field (Dick et al., 2006). Nonetheless, the validity of the basic rationale of this approach; namely, that the genetics of endophenotypes are simpler and therefore more amenable to molecular analysis than the genetics of clinical phenotypes; remains to be empirically tested (Flint \& Munafo, 2007).

The second strategy was first suggested in a highly influential 1996 publication by Risch and Merikangas (Risch \& Merikangas, 1996), who observed that the then predominant approach to gene identification, linkage analysis, had appeared to have reached its limit. As an alternative, they suggested that future progress would likely require the ability to systematically assay genetic variation across the whole genome by genotyping hundreds of thousands or maybe as many as one million genetic polymorphisms. In 1996, when investigations involving a couple of hundred genetic markers were considered path breaking, Risch and Merikangas's proposal seemed fanciful. Remarkably, within a decade, breakthroughs in high-throughput genotyping that have enabled the efficient genotyping of up to 1,000,000 polymorphisms has made Risch and Merikangas's proposal feasible and arguably the major approach currently in use for the genetic mapping of common disease.

Genome-wide association studies (GWASs) have resulted in the discovery of novel genetic variants affecting risk for a wide range of non-psychiatric diseases including macular degeneration, obesity, diabetes, breast cancer, and Crohn's disease (Iles, 2008). Although the number of published GWASs with psychiatric disorders is more limited, initial investigations of bipolar disorder (Sklar et al., 2008)and smoking (Bierut et al., 2007) give reason to be optimistic that this approach will also lead to discovery in the behavioral domain. Nonetheless, it is important to recognize that GWASs do not represent a panacea for the challenges of gene identification in behavioral genetics (Craddock, O'Donovan, \& Owen, 2008). Existing GWASs suggest that the effect of any single genetic variant on complex phenotypes is likely to be small, much smaller than originally anticipated. A recent GWAS of adult height, for example, found significant associations with 20 different genetic variants, collectively these variants accounted for only $3 \%$ of the phenotypic variation in height (Weedon et al., 2008). GWASs of behavioral traits will require massively large samples, which will likely only be feasible through 
collaborative efforts. Also, the GWAS approach is only applicable to the detection of common variants, and there is growing evidence that the genetic diathesis for some behavioral disorders, most notably autism, appears to be largely attributable to effect of multiple rare genetic mutations (Burmeister, McInnis, \& Zollner, 2008). Despite these limitations, the next 10 years is almost certain to see a large number of GWAS investigations of behavioral phenotypes.

\section{CONCLUSION}

This article began with an, admittedly rhetorical, question: The End of Behavior Genetics? The answer to this question may be yes for those with misplaced ideological misgivings or a fundamental misunderstanding of the nature and power of the reductionist paradigm (Rutter et al., 2001). It is remarkable to reflect back on the past 100 years and consider the enormous impact behavioral geneticists have had on psychology. The way we think about mental illness, human intellectual achievement, and personality has been changed irrevocably by behavioral genetic research. But the behavioral genetic research agenda has never been simply about establishing the heritability of behavior. Rather, behavioral genetics has sought first to establish the importance of genetic influences; next to identify the specific nature of the factors that underlie those influences; and ultimately to understand how these genetic factors combine and/ or interact with environmental factors to affect the development of complex behavioral phenotypes. The current vitality of the field owes in part to the power of its methodology but also to the as yet incomplete execution of this research agenda. Future progress will almost certainly depend on being able to identify the specific genetic polymorphisms that underlie behavior, a formidable task given the likely magnitude of specific genetic effects. Nonetheless, as we ponder the future of psychology over the next 100 years, it is inconceivable that behavioral genetics will not be at the center of many major breakthroughs in our understanding of the origins of human behavior, much like it has been at the center of many major breakthroughs over the past 100 years.

\section{Acknowledgments}

This paper is based in part on a presentation given at the 2008 biennial meeting of the Society for Research on Adolescence in Chicago Illinois. Research reported herein was supported in part from the following grants from the U.S. National Institutes of Health: AA09367, AA11886, DA05147, and MH066140

\section{REFERENCES}

Ando J, Nonaka K, Ozaki K, Sato N, Fujisawa KK, Suzuki K, et al. The Tokyo Twin Cohort Project: Overview and initial findings. Twin Research and Human Genetics 2006;9(6):817-826. [PubMed: 17254415]

Bergen SE, Gardner CO, Kendler KS. Age-related changes in heritability of behavioral phenotypes over adolescence and young adulthood: A meta-analysis. Twin Research and Human Genetics 2007;10(3): 423-433. [PubMed: 17564500]

Bierut LJ, Madden PAF, Breslau N, Johnson EO, Hatsukami D, Pomerleau OF, et al. Novel genes identified in a high-density genome wide association study for nicotine dependence. Human Molecular Genetics 2007;16(1):24-35. [PubMed: 17158188]

Bioethics, NCo. Genetics and human behaviour: The ethical context. London: Nuffield Council on Bioethics; 2002.

Blum K, Noble EP, Sheridan PJ, Montgomery A, Ritchie T, Jagadeeswaran P, et al. Allelic association of human dopamine D2 receptor gene in alcoholism. JAMA 1990;263(15):2055-2060. [PubMed: 1969501]

Bouchard TJ, McGue M. Familial studies of intelligence: A review. Science 1981;212(4498):1055-1059. [PubMed: 7195071]

Bouchard TJJ, Lykken DT, McGue M, Segal N, Tellegen A. Sources of human psychological differences: The Minnesota Study of Twins Reared Apart. Science 1990;250:223-228. [PubMed: 2218526] 
Burmeister M, McInnis MG, Zollner S. Psychiatric genetics: progress amid controversy. Nature Reviews Genetics 2008;9(7):527-540.

Busjahn A, Hur YM. Twin registries: An ongoing success story. Twin Research and Human Genetics 2006;9(6):705-705. [PubMed: 17254394]

Caspi A, McClay J, Moffitt TE, Mill J, Martin J, Craig IW, et al. Role of genotype in the cycle of violence in maltreated children. Science 2002;297:851-854. [PubMed: 12161658]

Caspi A, Sugden K, Moffitt TE, Taylor A, Craig I, Harrington HL, et al. Influence of life stress on depression: Moderation by polymorphism in the 5-HTT gene. Science 2003;301:386-389. [PubMed: 12869766]

Chipuer HM, Rovine MJ, Plomin R. Lisrel modeling: Genetic and environmental influences on IQ revisited. Intelligence 1990;14(1):11-29.

Cloninger CR, Bohman M, Sigvardsson S. Inheritance of alcohol abuse. Cross-fostering analysis of adopted men. Archives of Genearl Psychiatry 1981;38(8):861-868.

Collins LM, Murphy SA, Bierman KL. A conceptual framework for adaptive preventive interventions. Prevention Science 2004;5(3):185-196. [PubMed: 15470938]

Craddock N, O'Donovan MC, Owen MJ. Genome-wide association studies in psychiatry: lessons from early studies of non-psychiatric and psychiatric phenotypes. Molecular Psychiatry 2008;13(7):649653. [PubMed: 18504426]

Currier D, Mann MJ, Oquendo MA, Galfalvy H, Mann JJ. Sex differences in the familial transmission of mood disorders. Journal of Affective Disorders 2006;95(1-3):51-60. [PubMed: 16793141]

Devlin B, Daniels M, Roeder K. The heritability of IQ. Nature 1997;388(6641):468-471. [PubMed: 9242404]

Dick DM, Jones K, Saccone N, Hinrichs A, Wang JC, Goate A, et al. Endophenotypes successfully lead to gene identification: Results from the collaborative study on the genetics of alcoholism. Behavior Genetics 2006;36(1):112-126. [PubMed: 16341909]

Dierker LC, Avenevoli S, Goldberg A, Glantz M. Defining subgroups of adolescents at risk for experimental and regular smoking. Prevention Science 2004;5(3):169-183. [PubMed: 15470937]

Eaves L, Martin N, Heath A, Schieken R, Meyer J, Silberg J, et al. Age changes in the causes of individual differences in conservatism. Behavior Genetics 1997;27:121-124. [PubMed: 9145550]

Faraone SV, Biederman J. Familial transmission of attention deficit hyperactivity disorder and mood disorders. American Journal of Medical Genetics 1997;74(6):569-569.

Feldman MW, Lewontin RC. The heritability hang-up. Science 1975;190(4220):1163-1168. [PubMed: 1198102]

Finkel D, McGue M. Sex differences and nonadditivity in heritability of the Multidimensional Personality Questionnaire scales. Journal of Personality and Social Psychology 1997;72:929-938. [PubMed: 9108705]

Flint J, Munafo MR. The endophenotype concept in psychiatric genetics. Psychological Medicine 2007;37(2):163-180. [PubMed: 16978446]

Freedman DA. Statistical models for causation - What inferential leverage do they provide? Evaluation Review 2006;30(6):691-713. [PubMed: 17093105]

Fromm-Reichmann F. Notes on the development of treatment of schizophrenia by psychoanalytic psychotherapy. Psychiatry 1948;11:263-273. [PubMed: 18889231]

Galton F. Heredity talent and character. II. Macmillan's Magazine 1865;12:318-327.

Galton, F. Hereditary genius: An inquiry into its laws and consequences. London: MacMillan; 1869.

Galton F. The history of twins, as a criterion for the relative powers of nature and nurture. Journal of the Anthropological Institute 1876;5:391-406.

Galton, F. Inquiries into human faculty and its development. London: Macmillan; 1883.

Gelernter J, O'Malley S, Risch N, Kranzler HR, Krystal J, Merikangas K, et al. No association between an allele at the D2 dopamine receptor gene (DRD2) and alcoholism [see comments]. JAMA 1991;266 (13):1801-1807. [PubMed: 1832467]

Gillham, NW. A life of Sir Francis Galton: From African exploration to the birth of eugenics. Oxford: Oxford University Press; 2001. 
Goddard, HH. Human efficiency and levels of intelligence. Princeton, NJ: Princeton University Press; 1920.

Golub AL, Johnson BD. Alcohol is not the gateway to hard drug abuse. Journal of Drug Issues 1998;28 (4):971-984.

Goring HHH, Terwilliger JD, Blangero J. Large upward bias in estimation of locus-specific effects from genomewide scans. American Journal of Human Genetics 2001;69(6):1357-1369. [PubMed: 11593451]

Gottesman II, Gould TD. The endophenotype concept in psychiatry: Etymology and strategic intentions. American Journal of Psychiatry 2003;160(4):636-645. [PubMed: 12668349]

Gottesman, II.; Shields, J. Schizophrenia and genetics: A twin study vantage point. New York: Academic Press; 1972.

Harada S, Agarwal DP, Goedde HW, Tagaki S, Ishikawa B. Possible protective role against alcoholism for aldehyde dehydrogenase isozyme deficiency in Japan [letter]. Lancet 1982;2(8302):827. [PubMed: 6126701]

Harden KP, Turkheimer E, Loehlin JC. Genotype by environment interaction in adolescents' cognitive aptitude. Behavior Genetics 2007;37(2):273-283. [PubMed: 16977503]

Harris, JR. The nurture assumption: Why children turn out the way they do. London: Bloomsbury; 1998.

He MG, Ge J, Zheng YF, Huang WY, Zeng JW. The Guangzhou Twin Project. Twin Research and Human Genetics 2006;9(6):753-757. [PubMed: 17254403]

Heston LL. Psychiatric disorders in foster home reared children of schizophrenic mothers. British Journal of Psychiatry 1966;112:819-825. [PubMed: 5966555]

Hicks BM, Krueger RF, Iacono WG, McGue M, Patrick CJ. Externalizing disorders account for the genetic and environmental overlap between nicotine dependence and major depression. Archives of General Psychiatry 2004;61:922-928. [PubMed: 15351771]

Hicks BM, South SC, DiRago AC, Iacono WG, McGue M. Environmental adversity increases genetic risk for externalizing disorders. 2008

Higuchi S, Matsushita S, Murayama M, Tagaki S, Hayashida M. Alcohol and alcohol dehydrogenase polymorphisms and the risk of alcoholism. American Journal of Psychiatry 1995;152(1219-1221)

Hirschhorn JN, Lohmueller K, Byrne E, Hirschhorn K. A comprehensive review of genetic association studies. Genetics in Medicine 2002;4:45-61. [PubMed: 11882781]

Hur YM, Shin JS, Jeong HU, Han JY. The South Korean Twin Registry. Twin Research and Human Genetics 2006;9(6):838-843. [PubMed: 17254418]

Iacono WG, McGue M, Krueger RF. Minnesota Center for Twin and Family Research. Twin Research and Human Genetics. 2007 in press.

Iles MM. What can genome-wide association studies tell us about the genetics of common disease? Plos Genetics 2008;4(2)

Ioannidis JP, Ntzani EE, Trikalinos TA, Contopoulos-Ioannidis DG. Replication validity of genetic association studies. Nature Genetics 2001;29:306-309. [PubMed: 11600885]

Irons DE, McGue M, Iacono WG, Oetting WS. Mendelian randomization: A novel test of the gateway hypothesis. Development and Psychopathology 2007;19:1181-1195. [PubMed: 17931442]

Jackson C, Henriksen L. Do as I say: Parent smoking, antismoking socialization, and smoking onset among children. Addictive Behaviors 1997;22(1):107-114. [PubMed: 9022876]

Kandel, DB. Stages and pathways of drug involvement: Examining the gateway hypothesis. New York: Cambridge University Press; 2002.

Kandel DB, Yamaguchi K, Chen K. Stages of progression in drug involvement from adolescence to adulthood: Further evidence for the gateway theory. Journal of Studies on Alcohol 1992;53:447457. [PubMed: 1405637]

Kaprio J. Twin studies in Finland 2006. Twin Research and Human Genetics 2006;9(6):772-777. [PubMed: 17254406]

Kendler KS, Jacobson KC, Gardner CO, Gillespie N, Aggen SA, Prescott CA. Creating a social world A developmental twin study of peer-group deviance. Archives of General Psychiatry 2007;64(8): 958-965. [PubMed: 17679640] 
Keyes M, Legrand LN, Iacono WG, McGue M. Parent smoking and adolescent problem behavior: An adoption study of general and specific effects. American Journal of Psychiatry. 2008 in press.

Keyes MA, Iacono WG, McGue M. Early onset problem behavior, young adult psychopathology, and contextual risk. Twin Research and Human Genetics 2007;10(1):45-53. [PubMed: 17539364]

Kidd KK. Associations of disease with genetic markers; deja vu all-over again. American Journal of Medical Genetics (Neuropsychaitric Genetics) 1993;48:71-73.

Koenig LB, McGue M, Iacono WG. Stability and change in religiousness during emerging adulthood. Developmental Psychology 2008;44(2):532-543. [PubMed: 18331142]

Koenig LB, McGue M, Krueger RF, Bouchard TJ. Genetic and environmental influences on religiousness: Findings for retrospective and current religiousness ratings. Journal of Personality 2005;73(2):471-488. [PubMed: 15745438]

Legrand LS, Keyes MA, McGue M, Iacono WG, Krueger RF. Rural residency reduces the genetic influence on adolescent substance-use and rule-breaking behavior. Psychological Medicine. 2008 in press.

Lerner RM. Another nine-inch nail for behavioral genetics! Human Development 2006;49(6):336-342.

Li LM, Gao WJ, Lv J, Cao WH, Zhan SY, Yang HY, et al. Current status of the Chinese National Twin Registry. Twin Research and Human Genetics 2006;9(6):747-752. [PubMed: 17254402]

Lichtenstein P, Sullivan PF, Cnattingius S, Gatz M, Johansson S, Carlstrom E, et al. The Swedish Twin Registry in the third millennium: An update. Twin Research and Human Genetics 2006;9(6):875882. [PubMed: 17254424]

Lykken DT, Bouchard TJ, McGue M, Tellegen A. The Minnesota Twin Family Registry: Some initial findings. Acta Geneticae Medicae Et Gemellologiae 1990;39(1):35-70. [PubMed: 2392892]

Lyons MJ, True WR, Eisen SA, Goldberg J, Meyer JM, Faraone SV, et al. Differential heritability of adult and juvenile antisocial traits. Arch Gen Psychiatry 1995;52(11):906-915. [PubMed: 7487339]

Martin NG, Eaves LJ, Heath AC, Jardine R, Feingold LM, Eysenck HJ. Transmission of social attitudes. Proceedings of the National Academy of Sciences of the United States of America 1986;83(12): 4364-4368. [PubMed: 3459179]

McCartney K, Harris MJ, Bernieri F. Growing up and growing apart: A developmental meta-analysis of twin studies. Psychological Bulletin 1990;107(2):226-237. [PubMed: 2138795]

McGue M, Bouchard TJ. Genetic and environmental influences on human behavioral differences. Annual Review of Neuroscience 1997;21:1-24.

McGue, M.; Bouchard, TJJ.; Iacono, WG.; Lykken, DT. Behavioral genetics of cognitive ability: A life span perspective. In: Plomin, R.; McClearn, GE., editors. Nature, nurture and psychology. Washington DC: American Psychological Association; 1993. p. 59-76.

McGue M, Elkins I, Walden B, Iacono WG. Perceptions of the parent-adolescent relationship: A longitudinal investigation. Developmental Psychology 2005;41:971-984. [PubMed: 16351340]

McGue M, Iacono WG. The association of early adolescent problem behavior with adult psychopathology. American Journal of Psychiatry 2005;162(6):1118-1124. [PubMed: 15930060]

McGue M, Iacono WG. The adolescent origins of substance use disorders. International Journal of Methods in Psychiatric Research 2008;17(S1):S30-S38. [PubMed: 18543360]

McGue M, Iacono WG, Krueger R. The association of early adolescent problem behavior and adult psychopathology: A multivariate behavioral genetic perspective. Behavior Genetics 2006;36(4):591602. [PubMed: 16557361]

McGue M, Keyes M, Sharma A, Elkins I, Legrand L, Johnson W, et al. The environments of adopted and non-adopted youth: Evidence on range restriction from the Sibling Interaction and Behavior Study (SIBS). Behavior Genetics 2007;37(3):449-462. [PubMed: 17279339]

McGue M, Lykken DT. Genetic influence on risk of divorce. Psychological Science 1992;3:368-373.

Mednick SA, Gabrielli WF, Hutchings B. Genetic influences in criminal convictions: Evidence from an adoption cohort. Science 1984;224(4651):891-894. [PubMed: 6719119]

Mendlewicz J, Rainer JD. Adoption study supporting genetic transmission in manic-depressive illness. Nature 1977;268(5618):327-329. [PubMed: 887159] 
Merikangas KR, Stevens DE, Fenton B, Stolar M, O'Malley S, Woods SW, et al. Co-morbidity and familial aggregation of alcoholism and anxiety disorders. Psychological Medicine 1998;28(4):773788. [PubMed: 9723135]

Merikangas KR, Stolar M, Stevens DE, Goulet J, Preisig MA, Fenton B, et al. Familial transmission of substance use disorders. Archives of General Psychiatry 1998;55:973-979. [PubMed: 9819065]

Mischel, W. Introduction to personality. Austin, Tx: Holt, Rinehart and Winston; 1981.

Moffitt TE, Caspi A, Rutter M. Strategy for investigating interactions between measured genes and measured environments. Archives of General Psychiatry 2005;62:473-481. [PubMed: 15867100]

Neale, MC.; Cardon, LR. Methodology for genetic studies of twins and families. Dordrecht, The Netherlands: Kluwer; 1992.

Neiswanger K, Hill SY, Kaplan BB. Association and linkage studies of the TAQI A1 allele at the dopamine D2 receptor gene in samples of female and male alcoholics [see comments]. American Journal of Medical Genetics 1995;60(4):267-271. [PubMed: 7485259]

Noble EP. The D2 dopamine receptor gene: a review of association studies in alcoholism and phenotypes. Alcohol 1998;16(1):33-45. [PubMed: 9650634]

Otten R, Engels R, van de Ven MOM, Bricker JB. Parental smoking and adolescent smoking stages: The role of parents' current and former smoking, and family structure. Journal of Behavioral Medicine 2007;30(2):143-154. [PubMed: 17221319]

Pang ZC, Ning F, Unger J, Johnson CA, Wang SJ, Guo Q, et al. The Qingdao Twin Registry: A focus on chronic disease research. Twin Research and Human Genetics 2006;9(6):758-762. [PubMed: 17254404]

Pato CN, Macciardi F, Pato MT, Verga M, Kennedy JL. Review of the putative association of dopamine D2 receptor and alcoholism: A metaanalysis. American Journal of Medical Genetics 1993;48(2):7882. [PubMed: 8362930]

Pinker, S. The blank slate. New York: Penguin; 2002.

Plomin R, Daniels D. Why are children in the same family so different from one another? Behavior and Brain Sciences 1987;10:1-60.

Plomin R, Kennedy JKJ, Craig IW. The quest for quantitative trait loci associated with intelligence. Intelligence 2006;34(6):513-526.

Purcell S. Variance components models for gene-environment interaction in twin analysis. Twin Research 2002;6:554-571. [PubMed: 12573187]

Rhea SA, Gross AA, Haberstick BC, Corley RP. Colorado Twin Registry. Twin Research and Human Genetics 2006;9(6):941-949. [PubMed: 17254434]

Richardson K, Norgate SH. A critical analysis of IQ studies of adopted children. Human Development 2006;49(6):319-335.

Risch NJ, Merikangas KR. The future of genetic studies of complex human diseases. Science 1996;273:1516-1517. [PubMed: 8801636]

Rose RJ, Dick DM, Viken RJ, Kaprio J. Gene-environment interaction in patterns of adolescent drinking: Regional residency moderates longitudinal influences on alcohol use. Alcoholism: Clinical and Experimental Research 2001;25(5):637-643.

Rowe DC, Jacobson KC, Van den Oord E. Genetic and environmental influences on vocabulary IQ: Parental education level as moderator. Child Development 1999;70(5):1151-1162. [PubMed: 10546338]

Rutter M. Proceeding from observed correlation to causal inference: The use of natural experiments. Perspectives on Psychological Science 2007;2(4):377-395.

Rutter M, Pickles A, Murray R, Eaves LJ. Testing hypotheses on specific causal effects on behavior. Psychological Bulletin 2001;127:291-324. [PubMed: 11393298]

Rutter M, Silberg J. Gene-environment interplay in relation to emotional and behavioral disturbance. Annual Review of Psychology 2002;53:463-490.

Scarr S, McCartney K. How people make their own environments: A theory of genotype => environment effects. Child Development 1983;54:424-435. [PubMed: 6683622]

Shanahan MJ, Hofer SM. Social context in gene-environment interactions: Retrospect and prospect. Journal of Gerontology 2005;60B:65-76. 
Sklar P, Smoller JW, Fan J, Ferreira MAR, Perlis RH, Chambert K, et al. Whole-genome association study of bipolar disorder. Molecular Psychiatry 2008;13(6):558-569. [PubMed: 18317468]

Skytthe A, Kyvik K, Bathum L, Holm N, Vaupel JW, Christensen K. The Danish Twin Registry in the new millennium. Twin Research and Human Genetics 2006;9(6):763-771. [PubMed: 17254405]

Smith L, Watson M, Gates S, Ball D, Foxcroft D. Meta-analysis of the association of the Taq1A polymorphism with the Risk of alcohol depedency: A HuGE gene-disease association review. American Journal of Epidemiology 2008;167(2):125-138. [PubMed: 17989061]

Teasdale TW, Owen DR. Heredity and familial environment in intelligence and educational-level: A sibling study. Nature 1984;309(5969):620-622. [PubMed: 6728020]

Turkheimer E, Haley A, Waldron M, D'Onofrio B, Gottesman II. Socioeconomic status modifies heritability of IQ in young children. Psychological Science 2003;14:623-628. [PubMed: 14629696]

Uher R, McGuffin P. The moderation by the serotonin transporter gene of environmental adversity in the aetiology of mental illness: review and methodological analysis. Molecular Psychiatry 2008;13(2): 131-146. [PubMed: 17700575]

Wahlsten D. Insensitivity of the analysis of variance to heredity-environment interaction. Behavioral and Brain Sciences 1990;13(1):109-\&.

Watson, JB. Behaviorism (revised edition). Chicago: University of Chicago Press; 1930.

Weedon MN, Lango H, Lindgren CM, Wallace C, Evans DM, Mangino M, et al. Genome-wide association analysis identifies 20 loci that influence adult height. Nature Genetics 2008;40(5):575583. [PubMed: 18391952]

Weissman MM, Wickramaratne P, Nomura Y, Warner V, Pilowsky D, Verdeli H. Offspring of depressed parents: 20 years later. American Journal of Psychiatry 2006;163(6):1001-1008. [PubMed: 16741200]

Wender PH, Rosenthal D, Ketty SS, Schulsinger F, Welner J. Cross-fostering: A research strategy for clarifying the role of genetic and experimental factors in the etiology of schizophrenia. Archives of General Psychiatry 1974;30:121-128. [PubMed: 4808731]

Zubin J, Spring B. Vulnerability: A new view of schizophrenia. Journal of Abnormal Psychology 1977;86:103-126. [PubMed: 858828] 


\section{Concordance}

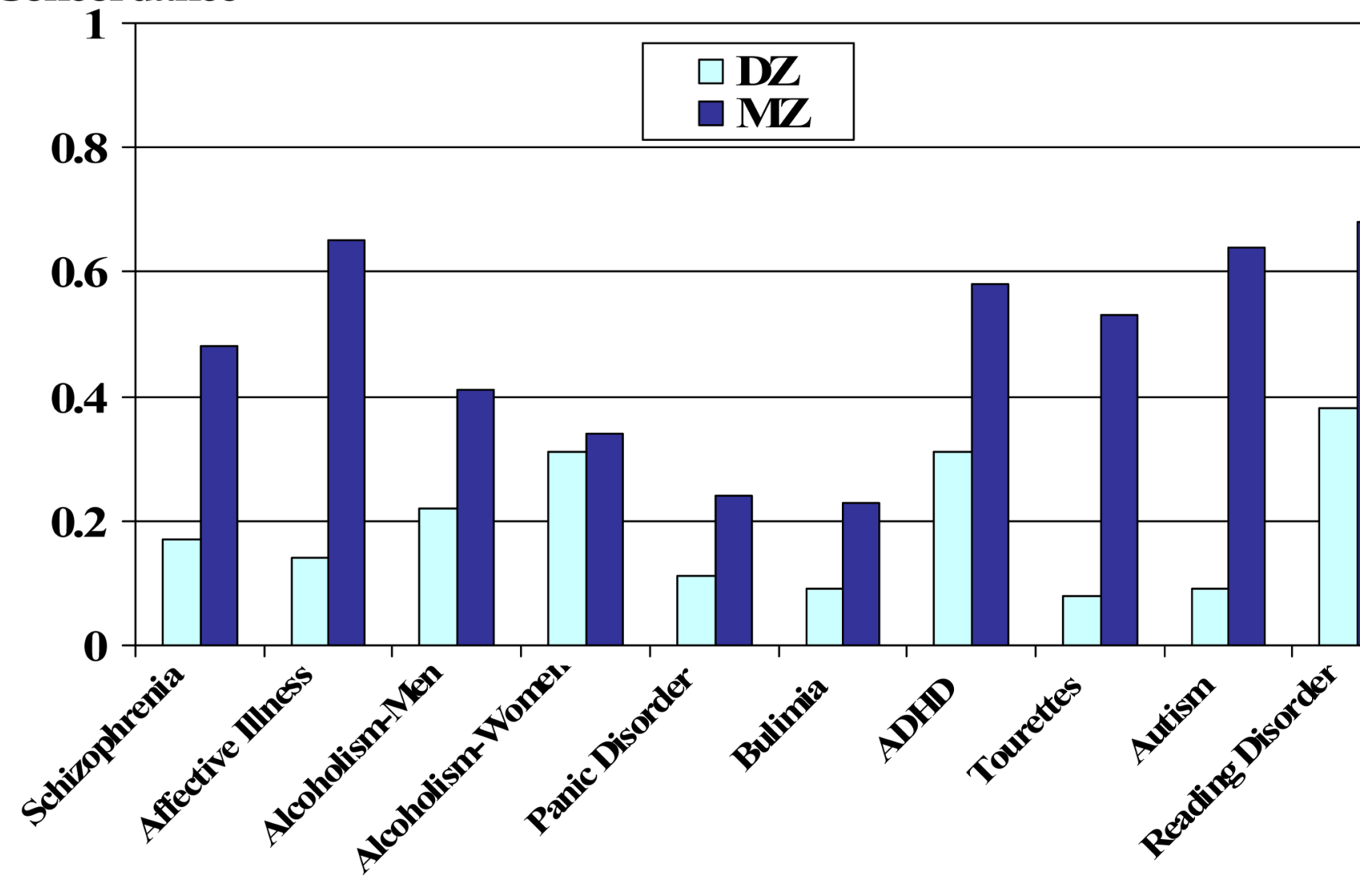

Figure 1.

Risk to monozygotic (MZ) and dizygotic (DZ) cotwins of twins affected with various mental disorders. Adapted from McGue and Bouchard (McGue \& Bouchard, 1997). 


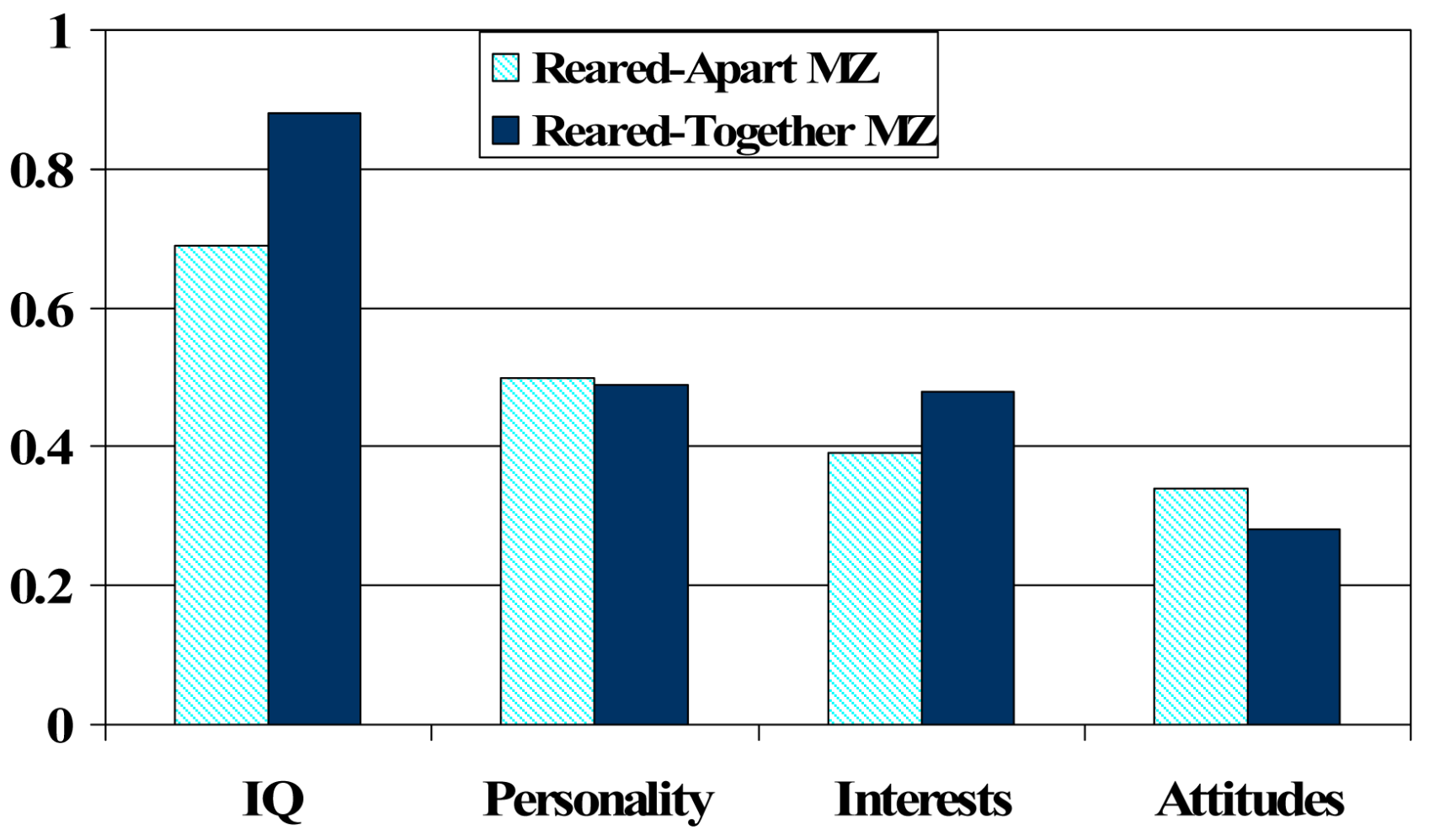

Figure 2.

Average reared-apart and reared-together monozygotic (MZ) twin correlations in four domains of psychological functioning. Adapted from Bouchard et al. (1990) 


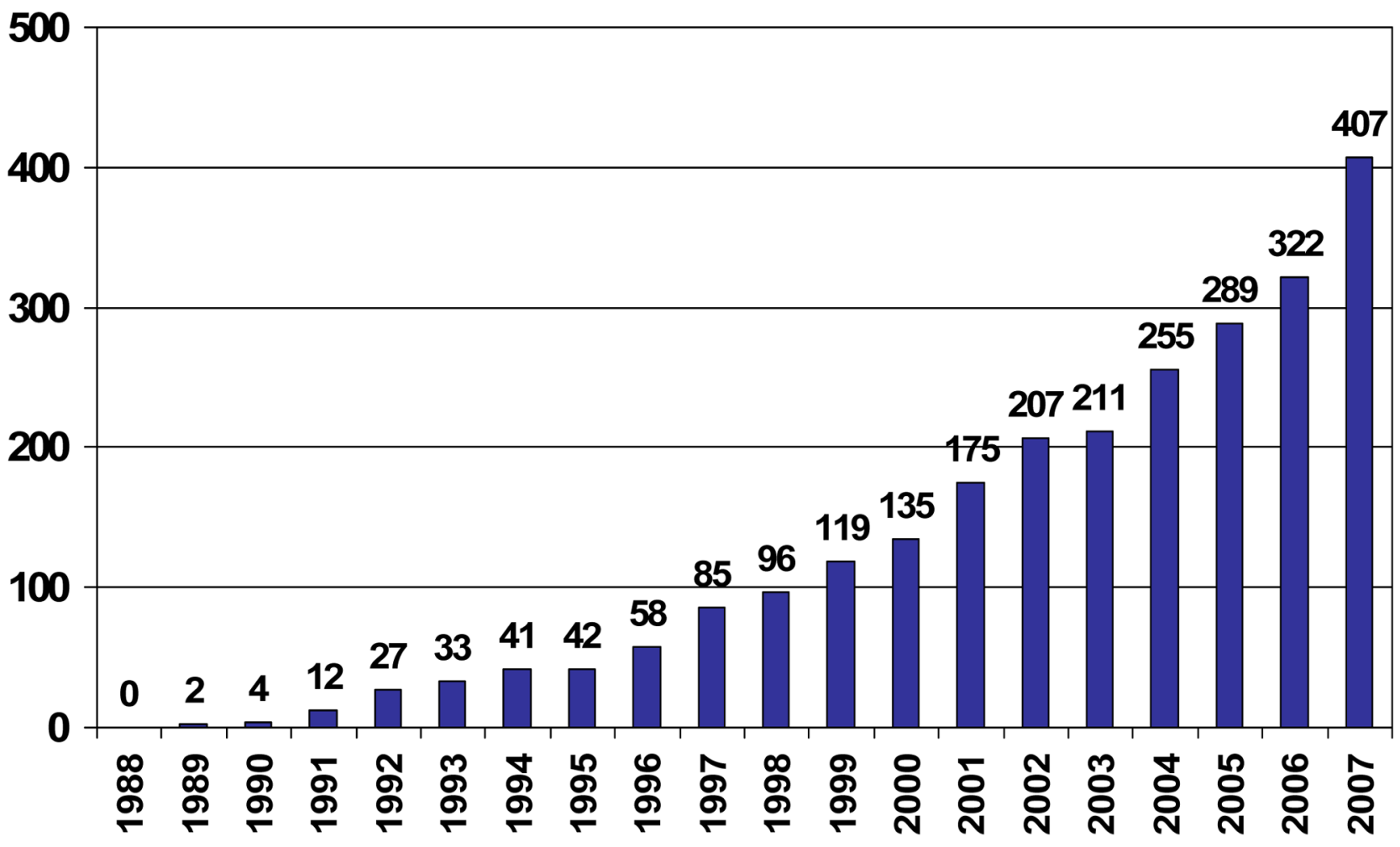

Figure 3.

Number of entries to "Gene Environment Interaction" in Thomson's Institute of Scientific Information database, 1988-2007. 


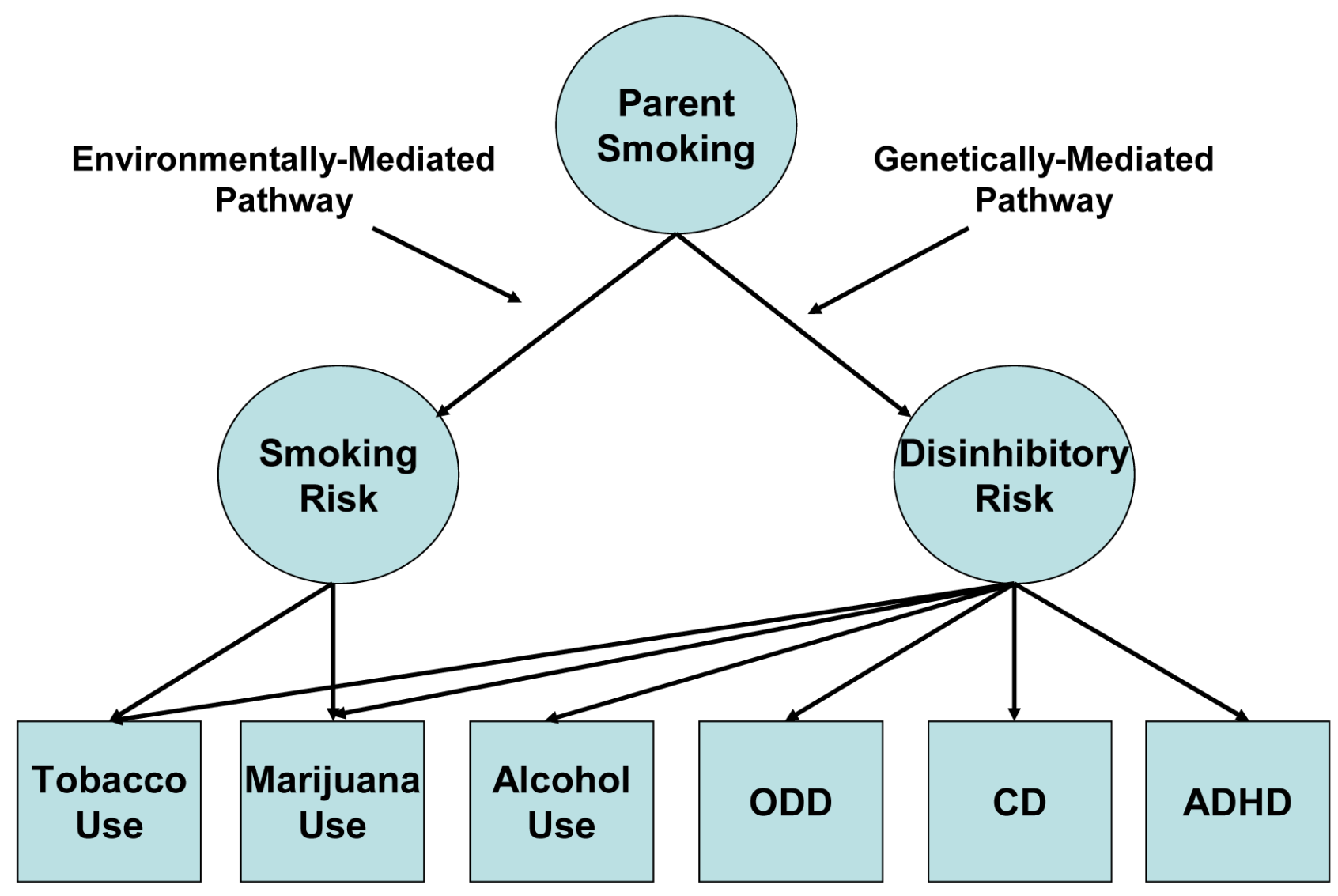

Figure 4.

Dual pathway model for the effects of parent smoking on adolescent functioning. Model is based on the adoption study findings by Keyes et al. (2008), which implicate the existence of a genetically-mediated pathway whereby parent smoking conveys generalized risk of disinhibitory psychopathology and substance abuse, and an environmentally mediated pathway whereby parent smoking conveys specific risk for adolescent smoking. ADHD = attention deficit/hyperactivity disorder, $\mathrm{CD}=$ conduct disorder, and ODD = oppositional defiant disorder. 


\section{Alcohol

\section{ADH}

ALDH

Figure 5.

Primary metabolic pathway for the elimination of alcohol. The vast amount of ethanol consumed by mammals is metabolized in a two-step process in the liver. Alcohol is first converted to the intermediate product, acetaldehyde, by the enzyme alcohol dehydrogenase $(\mathrm{ADH})$, which in turn is converted to acetate by the enzyme aldehyde dehydrogenase (ALDH) 